University of New Hampshire

University of New Hampshire Scholars' Repository

Earth Systems Research Center

Institute for the Study of Earth, Oceans, and

Space (EOS)

$9-2010$

\title{
Modeled nitrogen loading to Narragansett Bay: 1850 to 2015
}

\author{
Matthew A. Vadeboncoeur \\ University of New Hampshire, matt.vad@unh.edu \\ Steven P. Hamburg \\ Brown University \\ Donald Pryor \\ Brown University
}

Follow this and additional works at: https://scholars.unh.edu/ersc

Part of the Ecology and Evolutionary Biology Commons, and the Forest Sciences Commons

\section{Recommended Citation}

Vadeboncoeur MA, Hamburg SP, Pryor D. 2010. Modeled nitrogen loading to Narragansett Bay: 1850 to 2015. Estuaries and Coasts 33:1113-1127

This Article is brought to you for free and open access by the Institute for the Study of Earth, Oceans, and Space (EOS) at University of New Hampshire Scholars' Repository. It has been accepted for inclusion in Earth Systems Research Center by an authorized administrator of University of New Hampshire Scholars' Repository. For more information, please contact Scholarly.Communication@unh.edu. 


\title{
Modeled Nitrogen Loading to Narragansett Bay: 1850 to 2015
}

\author{
Matthew A. Vadeboncoeur \\ University of New Hampshire \\ Steven P. Hamburg \\ Environmental Defense Fund \\ Donald Pryor \\ Brown University
}

\begin{abstract}
Nutrient loading to estuaries with heavily populated watersheds can have profound ecological consequences. In evaluating policy options for managing $\mathrm{N}$, it is helpful to understand current and historic spatial loading patterns to the system. We modeled $\mathrm{N}$ inputs to Narragansett Bay from 1850-2000, using data on population, human waste disposal, livestock, fertilizer, and atmospheric deposition. We found that total $\mathrm{N}$ loading to the bay increased $250 \%$ from $1850-2000$, and $80 \%$ from $1900-2000$. Loading to the upper bay increased far more than that to the lower bay, and the most important source shifted from nonpoint animal waste to human waste concentrated at sewage treatment facilities. We also modeled future $\mathrm{N}$ loads in 2015 under four management scenarios. Planned improvements in sewage treatment would reduce $\mathrm{N}$ loads $9 \%$ below business-as-usual, to the 1990 loading rate. Greater reductions, to circa 1900 rates of loading, may be possible.
\end{abstract}

This reformatted accepted manuscript is made available by the authors, in accordance with Springer's author rights policy.

The final publication is available at www.springerlink.com; http://dx.doi.org/10.1007/s12237-010-9320-3

This document should be cited as:

Vadeboncoeur, M.A., S.P. Hamburg, and D. Pryor. 2010. Modeled nitrogen loading to Narragansett Bay: 1850 to 2015. Estuaries and Coasts 33(5): 1113-1127. 


\section{Introduction}

Over the past $150+$ years, humankind has drastically altered the global nitrogen cycle, via the combustion of fossil fuels, the planting of leguminous crops, and the Haber-Bosch process. Much of the $\mathrm{N}$ fixed by these processes ends up in rivers and estuaries. Because $\mathrm{N}$ often limits primary productivity in temperate estuaries (Howarth and Marino 2006), such systems are susceptible to eutrophication, leading to algal blooms, hypoxia, fish kills, and loss of benthic communities such as eelgrass beds (Bowen and Valiela 2001a). Recently, increased attention has turned to options for reducing the flux of $\mathrm{N}$ to estuarine systems (e.g. Howarth et al. 2002; Driscoll et al. 2003).

\section{Study system}

Narragansett Bay is a temperate estuary with a long history of intensive human use and impact (Nixon et al. 2008; Hamburg et al. 2008). The estuary (Figure 1) has a total surface area of $380 \mathrm{~km}^{2}$, a mean water depth of $8 \mathrm{~m}$ and tidal range of 1.1-1.9 $\mathrm{m}$. Mean flushing time is about 26 days (Pilson 1985), though the Lower Bay is flushed far more rapidly (via the East and West Passages) than the more stratified and isolated waters further inland. The watershed covers $4,400 \mathrm{~km}^{2}$, including most of Rhode Island and part of Massachusetts. Tributaries to Narragansett Bay, of which the largest are the Taunton, Blackstone, and Pawtuxet Rivers (Figure 1) have a mean combined flow of about $100 \mathrm{~m}^{3} \mathrm{~s}^{-1}$ (Pilson 1985).

Many changes in the ecology of Narragansett Bay observed over the past century are consistent with ecosystem stress from chronic nutrient loading. Eelgrass (Zostera marina) beds have been lost in much of the bay, blooms of nuisance algal species have increased, hypoxic events are widely observed, and shifts in the benthic and demersal-pelagic communities have become apparent (Deacutis 2008). A hypoxic event was blamed for killing more than a million fish which washed ashore in 2003 in Greenwich Bay, bringing increased public attention to the issue.

\section{Population change}

Human population is one of the most important determinants of $\mathrm{N}$ flux to large river systems (Cole et al. 1993). In 2000, the total population within the Narragansett Bay watershed (Figure 1b) was $1,936,000$. European settlement of the watershed began in 1636, but total population remained below 250,000 until 1850 . The watershed's largest cities constructed sewage systems around 1880 to accommodate rapidly growing populations, and many smaller cities followed by 1920 .

\section{Agricultural expansion and decline}

In the mid $19^{\text {th }}$ Century, southern New England was a patchy agricultural landscape (Harper 1918). There were over 9,200 farms in the watershed in 1850, with animal husbandry driving land use more than cultivated crops (e.g. in RI in 1865, $87 \%$ of cleared farmland was pasture or hayfield). Dairy cows and other cattle were the most abundant livestock, though horses were important in cities. Manure produced by city horses and barn-housed livestock would have lost substantial $\mathrm{N}$ during storage. On farms, pastures were often preferentially located near streams and on marginal wetlands unsuitable for cultivation. Proximity to streams is one factor controlling the leaching of waste N (Johnes 1996), though streamside wetlands can also be sites of efficient denitrification.

\section{Fertilizer use}

Fertilizer inputs in the northeastern United States have been estimated to account for $10-20 \%$ of total $\mathrm{N}$ input to estuaries (Howarth et al. 1996; Van Breemen et al. 2002). Agricultural activity was declining in the region when commercial fertilizers came into wide use after 1900, though per-acre usage of fertilizer in RI and MA was much higher than the national average (Haskell 1925; Mehring 1945). In the northeastern US, rates of $\mathrm{N}$ application to suburban lawns and gardens may now be equal to (Law et al. 2004) or even double that of field crops (Bowen and Valiela 2001a).

\section{Atmospheric Deposition of $N$}

The flux of fixed $\mathrm{N}$ in precipitation and dry deposition has increased dramatically since first measured in the northeast over 100 years ago, when it was already greatly elevated above pre-industrial levels (Bowen and Valiela 2001b; Galloway et al. 2004). Regionally, atmospheric $N$ is thought to contribute approximately $10-30 \%$ of total $\mathrm{N}$ flux to coastal waters (Roman et al. 2000; Castro et al. 2001; Driscoll et al. 2003; Howarth 2008). In forested watersheds most of the deposited $\mathrm{N}$ is generally retained in forested upland ecosystems (Campbell et al. 2004), even when deposition is high (Dise and Wright 1995; Magill et al. 2000). Aggrading forests represent a significant sink for this 
nitrogen (Goodale et al. 2002). Much current N deposition comes from sources far from Narragansett Bay, including the Midwest and midAtlantic region (Paerl et al. 2001).

\section{Conceptual Framework}

Nitrogen loading to Narragansett Bay is well studied. Nixon et al. (1995) compiled a budget based on late$20^{\text {th }}$ century concentration and flux data for major tributaries and point sources. Nixon et al. (2008) updated these datasets and placed them in the context of historical $\mathrm{N}$ flux estimates based on a variety of observations and methodologies. Boyer et al. (2002) constructed a detailed modern N budget for the Blackstone River watershed, among others in the region. Roman et al. (2000) estimated annual N concentration at an annual timestep for Narragansett Bay and several other estuaries from 1900-1995. Their analysis is very useful for comparing trends among the studied estuaries, though it is unclear how some important sources (e.g. point discharges directly to the bay) are treated in their analysis. We expand on these efforts by creating a loading model that is applied uniformly across time and space in the watershed, employing town-level datasets on drivers of $\mathrm{N}$ flux such as human population, disposal of human waste, landcover, livestock, fertilizer, and atmospheric deposition. The fine spatial resolution and consistency of these datasets over 150 years allows us to examine changes in the contribution of each source of $\mathrm{N}$ loading in each subwatershed. We validate the model using historic observations of $\mathrm{N}$ concentrations in three major tributaries, and with observation-based flux estimates over the past few decades. Finally, we estimate inputs in 2015 under three reduction scenarios as a heuristic tool to assess the effect of various potential management strategies.

Our model estimates $\mathrm{N}$ flux over time in a human influenced, dynamic, non-equilibrium system. Others (e.g. Howarth et al. 1996; Castro and Driscoll 2002) have estimated exogenous anthropogenic $N$ inputs to the watershed and modeled the fraction lost to rivers and estuaries. For recent decades this is a good approach for Narragansett Bay; $\mathrm{N}$ fluxes to the bay predominantly originate outside the watershed. $\mathrm{N}$ enters the watershed system largely through imports of food and fertilizer, and atmospheric deposition of anthropogenically-fixed $\mathrm{N}$. Some of this imported $\mathrm{N}$ makes it to the bay, though most is either denitrified or stored within the watershed system (in soils, groundwater, and forest biomass). Historically, though, soil N stocks within the watershed (replenished by biological $\mathrm{N}$ fixation) must have been a net source of $\mathrm{N}$ that was transported to the bay. Locally cycling $\mathrm{N}$ was transformed into food products and animal feed in rural towns, transported to cities where it was further transformed to human or animal waste, and finally discharged to the bay or large rivers via sewer systems and impervious surface runoff. For this reason, it is important to consider not just exogenous inputs to the watershed, but processes which move locally cycling $\mathrm{N}$ into pools susceptible to transport to the estuary.

We model long-term trends in $\mathrm{N}$ loading in several sub-basins of the Narragansett Bay watershed (Figure 1) to provide perspective for the current discussion about options for reducing $\mathrm{N}$ loads to the estuary. The impact and magnitude of management is best understood in context of the unique and complex history of changing human use of the watershed. Uniquely (to date), our model enables us to answer important questions, including: 1) how much have total $\mathrm{N}$ loads increased over the past 150 years? 2) How has the relative contribution of various sources to $\mathrm{N}$ loading changed over time? 3) In which parts of the watershed has $\mathrm{N}$ loading changed most dramatically over time? 4) How far "back in time" can various policy options for $\mathrm{N}$ load reduction take the ecosystem?

\section{Data and Methods}

\section{Modeling Approach}

Each independent variable, determined on a subwatershed basis (sewered and unsewered human populations, animal units, fertilizer usage, and atmospheric deposition), was multiplied by literature-derived loading coefficients in order to estimate the $\mathrm{N}$ load from each source within each subwatershed. These data generally exist for the period 1850-2000 at the town level, so we defined each subwatershed as the aggregation of all towns that lay at least $50 \%$ within each hydrologic basin (Figure 1b). Subwatersheds were defined by those locations with the most complete long-term records of $\mathrm{N}$ concentrations in rivers (Figure $1 \mathrm{~b}$ ).

Population and human waste disposal

Population data by town are available from the US Census for all years modeled (Online Resource 1). Populations served by sewers (Online Resource 1) 
were estimated using data from Harris (1913), Gage (1922), RI Department of Health (1936), the 19601990 Federal Census of Housing, and Patenaude (2000). Sewered populations prior to 1910 were estimated assuming a linear increase in the fraction of each city's population served between the date sewer construction began and the year of the first published population served data. Un-sewered populations were calculated by difference.

\section{Fertilizer}

We calculated fertilizer use in each subwatershed based on the fraction of each county's area within the basin, assuming spatially uniform fertilizer use within counties (Boyer et al. 2002). The 2000 rates of $\mathrm{N}$ application for our subwatersheds range from $5.7 \mathrm{~kg} \mathrm{~N} \mathrm{ha}^{-1} \mathrm{yr}^{-1}$ (Blackstone) to $14.8 \mathrm{~kg} \mathrm{~N} \mathrm{ha}^{-1} \mathrm{yr}^{-1}$ (Lower Bay), similar to rates (9.5-12.5 kg N ha ${ }^{-1} \mathrm{yr}^{-1}$ ) reported by Law et al. (2004) for suburban Maryland.

County-level fertilizer expenditures are reported in state censuses for 1885-1905 and in the Federal agricultural census for 1910-1920. State and national totals are used to scale the 1885 data for earlier years. Dollar amounts were converted to mass using 1885 price data for MA and state-total tonnage from 1913-1920 (Haskell 1925; Lipman 1929). County total tonnage for $1930-1940$ are reported by the Federal agricultural census. $\mathrm{N}$ content was calculated using mean $\mathrm{N}$ concentrations for 1880-1945 reported by Mehring and Peterson (1934) and the Census. For 1945-2001, fertilizer N content data are reported by county (Alexander and Smith 1990; Ruddy et al. 2006). High relative uncertainty pre-1930 is mitigated by low application rates. Online resource 2 shows commercial fertilizer use by subwatershed calculated from these data.

\section{Atmospheric Deposition}

Bowen and Valiela (2001b) compiled historical data on total atmospheric $\mathrm{N}$ deposition throughout the northeast, and modeled the secular trend as a linear increase of $0.26 \mathrm{~kg} \mathrm{~N} \mathrm{ha}^{-1} \mathrm{yr}^{-1}$ per decade, from 8.4 kg N ha ${ }^{-1} \mathrm{yr}^{-1}$ in 1910, to $10.6 \mathrm{~kg} \mathrm{~N} \mathrm{ha}^{-1} \mathrm{yr}^{-1}$ in 2000. We used this model at all time steps, back-casting to a value of $6.9 \mathrm{~kg} \mathrm{~N} \mathrm{ha}^{-1} \mathrm{yr}^{-1}$ in 1850 in the absence of any data. This value is consistent with the estimate for 1860 by Galloway et al. (2004). N deposition to each subwatershed was calculated as the product of deposition rate and area. We also calculated atmospheric deposition directly to Narragansett Bay, scaling the deposition rate for each year by 0.68 , to account for lower dry deposition rates to water bodies (Meyers et al. 2001).

Land-cover

The land-cover history of the Narragansett Bay watershed is broadly similar to that of other wellstudied systems (e.g. Chesapeake Bay; Brush 2009), though currently agriculture is a much less important land use in southern New England than the midAtlantic region. Because changes in land-cover affect the amount of atmospheric $\mathrm{N}$ reaching estuaries (Fisher and Oppenheimer 1991), it is important to account for land-cover change over the modeled time period. Federal and state agricultural censuses were used to describe town-level changes in active agricultural land (plowed land, mowed land, and active pasture) from 1850-1930. We used the 1992 National Land Cover Dataset to summarize 1990 land cover in three classes: agricultural, urban/developed, and forest. We estimated 2000 land cover by increasing 1990 developed land at the expense of forest at three times the rate of each town's population growth (Novak and Wang 2004; RI Statewide Planning 2006). We assumed the amount of urban/developed land increased proportionally with population from 1850-1990, and assumed a linear decrease in agricultural land between 1930 and 1990. Land-cover history data compiled from these sources in each modeled subwatershed are showin in Figure 2 and Online Resource 3.

\section{Livestock}

Livestock populations in each town (horses, dairy cows, oxen, other cattle, sheep, and swine) were tabulated using the Federal Agricultural Census schedules for 1850,1860 , and 1870 . State censuses continue the record to 1905; decennial estimates were interpolated between state census years (Online Resource 4a). After 1905, only county-level data are published. These data were used, along with the 1905 ratio of each county to each subwatershed, to estimate animal units by subwatershed in subsequent years. Livestock not on farms (horses and dairy cows) were not reported in Federal statistics before 1900, though they were reported in the RI state census (1875-85), and the Federal Census of Cities (1900-20). We used these data to create regressions of animal units vs. population $\left(R^{2}\right.$ values all $\left.>0.7\right)$ when direct data were not available (Online Resource 4b). We assume de minimus non-farm livestock after 1920 . 
Livestock numbers were converted to animal units (AU); which we defined such that one AU produces $100 \mathrm{~kg} \mathrm{~N} \mathrm{yr}^{-1}$ of waste (Online Resource 4b). Waste production estimates were summarized from agricultural and nutrient-loading literature (Thomas and Gillam 1977; Bleken and Bakken 1997; van Horn 1998; van der Hoek and Bouwman 1999; Smil 1999; Johnes 1996; Lander and Moffitt 1996). For each town at each time step, we calculated three estimates of AU. The middle estimate was based on the median waste $\mathrm{N}$ value in the literature; high and low values were based on consensus ranges from the above cited sources (Table 1) excluding only the extreme values for each animal type. There are few historical estimates of waste production, but they tend to be lower than modern values. Prior to modern farming methods, animals probably grew more slowly and produced less waste than their modern counterparts. Dairy cows are the beststudied, though perhaps most extreme example due to changes in feeding practices that have led to large increases in milk production per cow (Soll 2006): early estimates of waste production range from 46 to $90 \mathrm{~kg} \mathrm{~N} \mathrm{yr}^{-1}$ per dairy cow (Cornell University Agricultural Experimental Station Bulletin 1891; Roberts 1907). Therefore, our "mid" values of animal waste production and loading may be overestimates in the early part of the modeled period.

\section{Production and Export Coefficients}

We estimate human waste $\mathrm{N}$ production at $4.4 \mathrm{~kg} \mathrm{~N}$ $\mathrm{yr}^{-1}$ per capita (Vollenweider 1968). Valiela et al. (1997) use a value of $4.8 \mathrm{~kg} \mathrm{~N} \mathrm{yr}^{-1}$ per capita, and Howarth et al. (1996) use a value of $4.2 \mathrm{~kg} \mathrm{~N} \mathrm{yr}^{-1}$ per capita. The protein consumption of typical New Englanders has not changed appreciably over the past century (Briefel and Johnson 2004), so it is reasonable to use the modern value, $+/-25 \%$. All export coefficients relating to human waste $\mathrm{N}$ (Table 1) follow the approach used by Hamburg et al. (2008); and are based on literature values (Meybeck et al. 1989; Valiela et al. 1997; Castro et al. 2001; Van Breemen et al. 2002).

Delivery of animal waste $\mathrm{N}$ to surface waters is estimated using coefficients compiled and validated by Johnes (1996), with a further reduction for loss within higher order streams (Alexander et al. 2001; Seitzinger et al. 2002), resulting in loading estimates of 12.5 to $32 \%$ of input, with the "mid" estimate at $19 \%$ (Table 1). Some manure $\mathrm{N}$ applied to crops on cultivated land may have been lost at somewhat higher rates (Johnes 1996); we did not model this input separately because there are fewer historic data on cultivated land area than total cleared agricultural land, and data on rates of manure application to field crops are also lacking.

Howarth et al. (1996) estimate that 3-50\% of fertilizer and atmospherically deposited $\mathrm{N}$ applied to agricultural "grasslands" ultimately reaches an estuary, depending on soil type. Van Breemen et al. (2002) estimate 15-20\%, Fisher and Oppenheimer (1991) estimate 30\%, and Allingham et al. (2002) estimate $25 \%$. We use $25 \%$ as a middle value for fertilizer $\mathrm{N}$ applied to lawns and agricultural lands, and $20 \%$ for atmospheric deposition to agricultural lands. Fertilizer inputs tend to be applied in pulses when plant demand is high, while atmospheric inputs are relatively constant throughout the year. For the export of atmospheric $\mathrm{N}$ deposited to urban/developed land, we follow Fisher and Oppenheimer (1991), using a mid value of $65 \%$, and a range of $30-100 \%$. Magill et al. (2000) show that aggrading southern New England forests export only $1-15 \%$ of input $\mathrm{N}$, even under greatly elevated $\mathrm{N}$ deposition. We used this range to define our high and low estimates of export.

\section{Validations}

\section{Modern validation}

To assess the accuracy of modern $\mathrm{N}$ flux estimates, we compare our model output to the observationbased flux estimates of Nixon et al. $(1995 ; 2008)$ for the three largest subwatersheds and the whole bay in the 1980s and early 2000s. (n.b. this comparison necessitates aggregating towns differently than in Figure $1 \mathrm{~b})$. Though the whole-bay analysis of Nixon et al. (2008) excludes loading to the Sakonnet River, we estimate the effect of this difference at only $2 \%$ of total $\mathrm{N}$ flux to Narragansett Bay.

\section{Longitudinal validation}

We also compared our estimated flux data at four locations (Figure 1b) where both historical (18801925) and modern (1975-present) data are available on direct observations of $\mathrm{N}$ concentrations in river water. Historical $\mathrm{N}$ concentration data were reported as various combinations of "free ammonia" $\left(\mathrm{NH}_{4}^{+}\right.$), "albuminoid ammonia" (dissolved plus particulate organic N; Hamlin 1990), and nitrate. These partial data were converted to estimated total $\mathrm{N}$ flux using modern ratios of each measured dissolved $\mathrm{N}$ pool to total $\mathrm{N}$, and long-term mean flow data from nearby river gages. Across all watersheds, 
the mean modern ratio of TN:TDN was 1.47 . Modern USGS data include chemistry at each sampling date; we calculated annual TN flux as the mean of daily TN flux on all sampling days, excluding years with $<4$ samples.

\section{Management Scenarios}

We estimated total $\mathrm{N}$ loading in the year 2015 under four policy scenarios (Table 2). Population projections are based on state agency estimates. Based on the performance of the Bucklin tertiary treatment systems in 2006, (Pryor et al. 2007) we estimate that a wastewater system designed to meet a summer (May-Oct) discharge standard of 5 $\mathrm{mg} \mathrm{N}{ }^{-1}$ will result in annual mean loads of $8 \mathrm{mg} \mathrm{N} \mathrm{I}^{-1}$, and one meeting an $8 \mathrm{mg} \mathrm{N}^{-1}$ summer standard will result in an annual mean output of $10 \mathrm{mg} \mathrm{N} \mathrm{I}^{-1}$. Extrapolating, we estimate that a theoretical system designed to meet a summer standard of $3 \mathrm{mg} \mathrm{N}^{-1}$ would have a mean output of $5 \mathrm{mg} \mathrm{N}^{-1}$. For each wastewater treatment facility we calculated the percent reduction expected based on actual $\mathrm{N}$ loads from approximately the year 2000 (Pryor et al. 2007).

In our two more aggressive reductions scenarios (Table 2), we assumed reductions of $25 \%$ and $50 \%$ in the rate of atmospheric deposition. Driscoll et al. (2003) suggest that reductions required in recent years may reduce deposition $50 \%$ by 2025 in the US, but this estimate is tempered by the lack of evidence of declines in regional $\mathrm{N}$ deposition thus far (Howarth 2008). Land-use was assumed to continue to change along the 1980-1995 trajectory described by RI Statewide Planning (2006). We assumed no net increase in livestock populations, or in the fraction of population served by sewers. The most aggressive scenario (S3; Table 2) includes reductions not likely to be achievable by 2015 , and is included for heuristic purposes.

Because the forward-looking model estimates sewage load reductions based on the ratio of a concentration-based standard to the current annual mean $\mathrm{N}$ concentration of effluent at each sewage facility, whereas the historic model estimates flux based on population and average sewage treatment efficiency data, any disagreement between modeled and observed sewage output for 2000 will be carried forward to 2015. However the predictions are still useful in placing expected reductions in the context of the larger current and historical $\mathrm{N}$ budget of Narragansett Bay.

\section{Results}

$N$ loading by source

Our results (Figure 3) show that over time the relative importance of $\mathrm{N}$ sources to loading have shifted dramatically. In 1850, our mid-case model predicts total $\mathrm{N}$ loading at 2,250 $\mathrm{Mg} \mathrm{N} \mathrm{yr}^{-1}$, of which $18 \%$ was attributable to human waste, $51 \%$ to animal waste (though note that this flux may be somewhat overestimated), and $31 \%$ to atmospheric deposition (fertilizer was negligible). Total $\mathrm{N}$ loading increased slowly until 1870, then increased $80 \%$ between 1880 and 1910, due to rapid population growth and the construction of sewage systems in the watershed's major urban centers. From 19101950 , the further increase due to population growth and sewer construction was partially offset by declining livestock populations. Commercial fertilizer contributed little to total loading (<3\%) before 1950, but by 1970 it surpassed animal waste as a source of $\mathrm{N}$ loading (Figure 3 ). Atmospheric deposition to the watershed has increased slowly, but reversion of abandoned agriculture to forest (Figure 2) partially offset this effect in terms of exported flux.

In 2000, our mid-case model estimates 8,000 Mg N $\mathrm{yr}^{-1}$ of $\mathrm{N}$ loading to Narragansett Bay, of which $51 \%$ was from human waste delivered via sewage systems, $14 \%$ from human waste via septic systems and cesspools, $2 \%$ from animal waste, $13 \%$ from fertilizer, and $20 \%$ from atmospheric deposition. Animal waste went from being the dominant source in 1850, to the smallest modeled source in 2000. Overall, modeled $\mathrm{N}$ loading to Narragansett Bay increased $250 \%$ from 1850 to 2000 .

\section{$N$ loading by subwatershed}

Because we aggregated data by subwatershed (Figure 1b), our model can be used to assess changes in the contribution of each subwatershed to total $\mathrm{N}$ loading to Narragansett Bay (Figure 4). In 1850, towns adjacent to the Upper Bay accounted for only $16 \%$ of total $\mathrm{N}$ land-based loading; that share was approximately $30 \%$ from $1900-1950$, but only $26 \%$ in 2000. By contrast, the towns and cities adjacent to the Lower Bay, which accounted for an estimated $13 \%$ of all land-based loading in 1850 , contributed only $7 \%$ by 1950 . In the cities and towns of the Upper Bay, trends in total $\mathrm{N}$ loading are dominated by the effect of human waste delivered via sewers. The majority of the increase in $\mathrm{N}$ loads between 1880 and 1910 can be attributed to the growth of 
sewered populations in Providence and Fall River (on the Upper Bay), as well as Worcester, (in the Blackstone subwatershed).

\section{Modern validation}

Our mid-case estimates were in nearly all cases the best approximation of modern measured $\mathrm{N}$ flux in each sub-basin and to Narragansett Bay as a whole (Table 3), though our model predicted increased $\mathrm{N}$ flux in two rivers (the Blackstone and Pawtuxet) where Nixon et al. (2008) observe decreased flux between 1982 and 2003. These decreases are attributed by Nixon et al. (2008) to improvements in sewage treatment in Woonsocket and Cranston, respectively, and such differences are not accounted for in our model because there are few data on sewage treatment efficiency at the various facilities over time. This effect is also apparent in our estimates of $\mathrm{N}$ flux to the watershed as a whole; our mid-estimate increases approximately $11 \%$ between 1985 and 2000, while Nixon et al. (2008) estimate a $4 \%$ reduction.

\section{Longitudinal validation}

The earliest direct sampling of water quality in the watershed occurred in the late $19^{\text {th }}$ Century. Unfortunately, there are no continuous datasets since that time. We assembled the most complete data sets of paired historic and modern locationspecific water quality data for the three largest tributaries to Narragansett Bay (Figure 1).

In the Taunton subwatershed, no single location has a long-term record of $\mathrm{N}$ concentrations. USGS data for 1996-2002 were taken near Bridgewater (Figure 1b), showing an average annual $\mathrm{N}$ flux of $1,580 \mathrm{Mg} \mathrm{N}$ $\mathrm{yr}^{-1}$. Our mid-estimate for 2000 was 1,070 (520$1,780) \mathrm{Mg} \mathrm{N} \mathrm{yr}^{-1}$, (Figure 5a). Water quality data were taken at Taunton from 1898-1915 (MSDH 1915), 20 km downstream. Flux was calculated assuming $15 \%$ greater flow than at Bridgewater, based on the ratio of watershed areas. TN flux in 1898 was $200 \mathrm{Mg} \mathrm{N} \mathrm{yr}^{-1}$, which rose rapidly and then averaged $720 \mathrm{Mg} \mathrm{N} \mathrm{yr}^{-1}$ from 1903-1915. Our modeled estimate for 1900 is $620(330-1,200) \mathrm{Mg} \mathrm{N}$ $\mathrm{yr}^{-1}$, and the estimate for 1920 is $710(360-1,270) \mathrm{Mg}$ $\mathrm{N} \mathrm{yr}^{-1}$ (Figure 5a).

Water quality data for the Pawtuxet River at Pettaconsett, the former Providence water supply, were reported by the City Engineer from 1876-1905. Flux was calculated using late $20^{\text {th }}$ century flow data, correcting for modern withdrawals above Pettaconsett. Total $\mathrm{N}$ flux from this period averaged
$170 \mathrm{Mg} \mathrm{N} \mathrm{yr}{ }^{-1}$, with no significant trend. These data probably understate total $\mathrm{N}$ because organic $\mathrm{N}$ analyses of the time generally gave spuriously low results (Hamlin 1990). Our modeled mid-estimate is nearly constant between 1870 and 1910, ranging from 220-250 Mg N yr ${ }^{-1}$. Inorganic $\mathrm{N}$ reported by Gage and McGouldrick (1925) shows a generally increasing trend between 1901 and 1925 at Pettaconsett. Based on the relationship between these values and a minimum value for TN estimated using albuminoid $\mathrm{N}$ data for 1901-1905, total $\mathrm{N}$ fluxes ranged from $110 \mathrm{Mg} \mathrm{N} \mathrm{yr}^{-1}$ (1906-1910) to 300 Mg N yr ${ }^{-1}$ (1921-1925). Our mid-case model shows $\mathrm{N}$ flux declining slowly during this time period, from $250 \mathrm{Mg} \mathrm{N} \mathrm{yr}^{-1}$ in 1900 to $210 \mathrm{Mg} \mathrm{N} \mathrm{yr}^{-1}$ in 1930 (Figure 5b).

USGS flow and TN data were taken from 1978-2002 at Pettaconsett. TN flux during this time period averaged $510 \mathrm{Mg} \mathrm{N} \mathrm{yr}^{-1}$, ranging from 320-1000 Mg $\mathrm{N} \mathrm{yr}^{-1}$ with no significant trend. A comparison of these data with our model results shows our mid estimate lies within the wide range of interannual variability in observed TN loads, though observed loads do not show the short-term trend suggested by the model (Figure 5b).

DIN was measured in the Blackstone River at Millville, MA between 1887 and 1914 (MSDH 1915); and within a few km in 1923 (Gage and McGouldrick 1925). Intermittent sampling also occurred $17 \mathrm{~km}$ downstream at Albion RI, between 1885 and 1923 (Gage and McGouldrick 1925). TN has been measured at Millville and at Manville (near Albion) since 1979. Based on these data and scaled flow data from Woonsocket, we estimate mean TN flux at Manville at $840(400-1,620) \mathrm{Mg} \mathrm{N} \mathrm{yr}^{-1}$ in 1890, and 1,330 (770-2,180) Mg N yr $\mathrm{Mr}^{-1}$ in 1920 (Figure 5c). Since 1978, mean observed TN flux at Manville was $1,400 \mathrm{Mg} \mathrm{N} \mathrm{yr}^{-1}$. Our modeled estimates are 1,370 (770-2,140) Mg N yr ${ }^{-1}$ in 1980 and 1,540 (880-2,370) $\mathrm{Mg} \mathrm{N} \mathrm{yr}^{-1}$ in 2000 (Figure 5c).

At Millville, observed $\mathrm{N}$ flux values prior to 1898 match our modeled mid estimate fairly closely. However, the TN values observed at Millville between 1899 and 1914 depart rather dramatically from our mid-range estimates; two years exceed even the "high" estimate, while the 1923 value is approximately equal to our lower bound for 1920 . Total N flux observed at Millville has decreased dramatically since 1980 , though this may be in part attributable to a shift from 12 to 4 samples for each year, with most sampling dates in low-flow months. 
Mean observed TN at Millville for $1979-1983$ is 1,300 Mg N yr ${ }^{-1}$; our modeled mid-estimate for 1980 was $1,020(610-1,570) \mathrm{Mg} \mathrm{N} \mathrm{yr}^{-1}$. The mean for 1998 2002 was $700 \mathrm{Mg} \mathrm{N} \mathrm{yr}^{-1}$, while our modeled midestimate for 2000 was 1,190 (680-1,820) Mg N yr ${ }^{-1}$, (Figure 5d).

\section{Future N loading}

Without significant changes in sewage processing between 2000 and 2015 (i.e. tertiary treatment including nitrification and denitrification), the business-as-usual scenario predicts a $6 \%$ increase in land-based $\mathrm{N}$ loading, to $8,500 \mathrm{Mg} \mathrm{N} \mathrm{yr}^{-1}$. Assuming the agreed-upon $\mathrm{N}$ reduction targets are met by 8 sewage treatment plants (S1), total land-based loading would be reduced to $7,500 \mathrm{Mg} \mathrm{N} \mathrm{yr}^{-1}$, an $11 \%$ reduction relative to business-as-usual and equal to the estimate for 1990. Similar reduction targets applied to all RI facilities and the largest MA facilities, plus $25 \%$ reductions in atmospheric and fertilizer loads (S2) would result in a $27 \%$ reduction in land-based $\mathrm{N}$ inputs relative to business-as-usual, to $6,200 \mathrm{Mg} \mathrm{N} \mathrm{yr}^{-1}$, equaling the estimate for the mid-1970's. Approximately $68 \%$ of this reduction is due to sewage improvements. If all inputs are reduced aggressively (S3; Table 2 ), land-based $\mathrm{N}$ loading would be $4,200 \mathrm{Mg} \mathrm{N} \mathrm{yr}^{-1}, 50 \%$ below the business-as-usual scenario, which is equivalent to total $\mathrm{N}$ loading in the 1890 's. In all scenarios, sewage inputs remain the greatest contributor of $\mathrm{N}$ to Narragansett Bay, and watersheds draining to the upper bay dominate the reductions. In scenarios 2 and 3, the Lower Bay subwatershed (Figure 1) contributes only $5-6 \%$ to the total reductions.

\section{Discussion}

\section{Comparison with other models}

Castro and Driscoll (2002) summarize estimates of modern contributions to loading to Narragansett Bay in models with varying data inputs and theoretical frameworks, with total loading estimates ranging from 4,800 to $10,000 \mathrm{Mg} \mathrm{N} \mathrm{yr}^{-1}$. Point sources (sewage outfalls) are estimated as contributing 63$74 \%$ of the total, in comparison to our estimate of $51 \%$, while atmospheric inputs are estimated at 10 $21 \%$ (partly depending on whether direct deposition to the estuary waters is included), compared with our estimate of $20 \%$. The largest difference between our model and these others is our estimation that fertilizer (primarily non-agricultural) and septic systems are important non-point sources, together contributing $27 \%$ of total loading in 2000 .
Using an export-coefficient methodology similar to ours, Roman et al. (2000) estimate that the average $\mathrm{N}$ concentration of streamflow entering Narragansett Bay approximately doubled from 19001995 , with most of the increase occurring pre-1960. Our flux estimates increase steadily from 4,400 to $8,000 \mathrm{Mg} \mathrm{N} \mathrm{yr}^{-1}$ (80\%) from 1900-2000. Nixon et al. (2008) estimate a 60\% increase from 1900 to 1985 $(5,200$ to 8,400$) \mathrm{Mg} \mathrm{N} \mathrm{yr}^{-1}$ using a variety of observations and correction factors. The methodology employed by Roman et al. (2000) is not described in detail, so it is difficult to determine the cause of the relatively small difference in estimates. The question of whether flux was roughly constant or steadily increasing over the past 40 years has large implications for how we think about managing Narragansett Bay. If the system has been experiencing large steady increases in $\mathrm{N}$ inputs there is no reason to expect that biological communities are in equilibrium in terms of how $\mathrm{N}$ is cycled.

\section{Sources of uncertainty and systematic error}

Our model is necessarily simple in its approach due to its long temporal span and large historic shifts in the sources of $\mathrm{N}$ loading. Trends in the magnitudes of $\mathrm{N}$ inputs via fertilizers, animal waste, human waste inputs to septic systems and sewers were assumed to be the primary drivers of long-term trends in $\mathrm{N}$ loading to the estuary. We also assumed implicitly that loading derived from each source relates linearly to the magnitude of that source, based on ranges of loading coefficients (Table 1) derived from published research in comparable watersheds. Only for atmospheric deposition are changes in land cover used to modify the overall loading coefficient over time. To a first order approximation, this approach does reasonably well at explaining long-term trends in total $\mathrm{N}$ loading. There are, however, many complexities of $\mathrm{N}$ cycling within the watershed not included in the model, a few of which we discuss below.

The assumption that a constant loading coefficient linearly relates the magnitude of each $\mathrm{N}$ source to the output to receiving waters is an oversimplification. For example, Dise and Wright (1995) found a threshold relationship between $\mathrm{N}$ deposition and $\mathrm{N}$ leaching from forest ecosystems. Other threshold effects may relate to cumulative $\mathrm{N}$ inputs over time. Realistically, the rates of $\mathrm{N}$ export derived from fertilizer or manure inputs to soil are determined by application rate, precipitation amount, soil permeability, soil moisture, soil C:N 
ratio, temperature, plant demand, and proximity to waterways, among other variables. Our intention in using wide ranges for export coefficients (Table 1) was to account for this uncertainty, much of which may average out across a watershed and over multiple years.

Bowen and Valiela (2001b) show a clear shift in the form of inorganic $\mathrm{N}$ deposition over the 20th century. Early in the modeled period, $\mathrm{N}$ deposition occurred primarily in the form of ammonium, produced largely by volatilization from livestock waste and natural soil processes. There is some potential for "double counting" of this $\mathrm{N}$ to the extent that short-distance transport of locally volatilized $\mathrm{N}$ may be included in the $\mathrm{N}$ loading coefficients of Johnes (1996). Modern N deposition, in contrast, is dominated by oxidized $\mathrm{N}$, primarily originating from fossil fuel combustion. $\mathrm{N}$ deposited as nitrate is more susceptible to leaching from ecosystems, so leaching has likely increased more rapidly than total DIN deposition over the past 150 years. The wide ranges we afford each loading coefficient (Table 1) are intended in part to account for such uncertainty and hopefully accommodate this shift.

\section{What can be learned from the validation exercise}

Observed $\mathrm{N}$ fluxes show high interannual variability (Figure 5), and are not measured consistently or precisely enough to show modest changes over long periods of time, while our modeling approach is intended to show secular trends but cannot predict interannual variance. Comparing observed trends in $\mathrm{N}$ flux with our model outputs, which assume constant parameters relating $\mathrm{N}$ waste production to estuary loading, allows us to infer how processes controlling loading might have departed from our assumptions at various times over the past 150 years. For example, $\mathrm{N}$ fluxes in the Blackstone River at Millville between 1905 and 1913 depart dramatically from our mid-case model estimate, which they fit rather well prior to 1905 (Figure 5d). The largest source of $\mathrm{N}$ loading at this time was the Worcester sewage facility, which removed less $\mathrm{N}$ than our model assumes in1920 (Nixon et al. 2008). Poor N-removal as the population served by this system grew rapidly may explain some of the extreme values in this time period.

Historical total $\mathrm{N}$ fluxes used to validate our model (Figure 5) are largely based on a ratio of total $\mathrm{N}$ to DIN derived from modern data. Historic organic $\mathrm{N}$ data are unreliable (Hamlin 1990). As expected, a comparison of historic and modern $\mathrm{N}$ concentration data at Pettaconsett (Figure $5 \mathrm{~b}$ ) suggests that organic $\mathrm{N}$ constituted a greater fraction of total $\mathrm{N}$ circa 1900 than it does today. In 1900 the largely cleared landscape would have leached more DON than the forested landscapes of today (Willett et al. 2004). Changes in land-use (Figure 2), river engineering, and groundwater withdrawals must have affected runoff and groundwater flows to each river. In fact the abrupt change in the relationship between our model output for the Pawtuxet River and observed DIN flux (scaled to approximate TN flux in Figure 5b) occurred in the 1920's during the construction of the Scituate Reservoir upstream, though this may be largely a temporary response to the large-scale ecosystem disturbance associated with the reservoir project.

Interannual hydrologic variability is implicitly included in the ranges of loading coefficients we used (Table 1). Fluxes from non-point sources (fertilizers, animal wastes, and atmospheric-derived $\mathrm{N}$ transported from the landscape to receiving waters via runoff and leaching), in particular, would be expected to be greater in years with more precipitation, while point source fluxes (sewer outfalls) tend to be more constant. The deviation of modern flux estimates (1978-2002) from our "mid" estimate show significant positive correlations with annual precipitation (NWS data from Warwick, RI) at Manville and Pettaconsett, but not Bridgewater or Millville. However, our model indicates that the subwatershed above Bridgewater has the greatest relative contribution of atmospheric deposition, fertilizer, and animal waste (35-43\%, 1980-2000).

\section{Implications for management}

Nixon et al. (2008) use reports of eelgrass in the Providence River in 1865 (Doherty 1995) and published constraints on $\mathrm{N}$ loading per estuarine area to argue that $\mathrm{N}$ loading to the Providence River at this time was very low, less than $77 \mathrm{Mg} \mathrm{N} \mathrm{yr}^{-1}$. Today, eelgrass occurs primarily in the less urban and more rapidly flushed areas of the estuary. Eelgrass populations are affected not only by water column N concentrations, but also by light conditions, water temperature, and also a slime mold that decimated populations region-wide in the 1930s, so historical populations may have responded differently to nutrient stress. Our model predicts loading of $560(230-1,150) \mathrm{Mg} \mathrm{N} \mathrm{yr}^{-1}$ just from the Blackstone River above Manville (Figure 4), and loading from other areas draining to that area would 
add at least $200 \mathrm{Mg} \mathrm{N} \mathrm{yr}^{-1}$, making our estimate of loading to upper Providence River in 1865 an order of magnitude greater than that of Nixon et al. (2008). The majority of this estimated load is from animal waste (Figure 4), which may be overestimated somewhat due to changes over time in the amount of waste produced per animal. Even our "low" estimates are several times larger than those of Nixon et al. (2008). It is difficult to imagine that historical agro-systems were so much more efficient in their retention of animal waste and atmospherically deposited $\mathrm{N}$ than the modern pasture-based systems from which we derive our loading parameters. To the degree that eelgrass beds indicate a functional ecosystem in a relatively natural state, the total loading to this area in 1865 may represent an important threshold loading value, though admittedly one unlikely to be achieved in the foreseeable future through any combination of management decisions.

In the late $19^{\text {th }}$ and early $20^{\text {th }}$ Centuries, the increase in total $\mathrm{N}$ load was largely due to population growth and sewer construction in the watershed's major cities, most of which discharge directly to the Upper Bay (Figure 4). Currently, most growth in $\mathrm{N}$ loading comes from more suburban areas, including the Taunton watershed and in the other small watersheds surrounding Providence (Figure 4), suggesting a possible target for future mitigation efforts once point-source urban sewer systems are addressed.

The waters of the upper bay, which have seen the most dramatic rise in $\mathrm{N}$ loading, are also more prone to stratification, a necessary precondition for the formation of hypoxic water. Fulweiler et al. (2007) suggest that altered climatic regimes in the Bay have shifted the biogeochemistry of the lower bay, leading to increased $\mathrm{N}$ fixation in sediments. However, because the upper and lower portions of the Bay are on different trajectories, the effects of $\mathrm{N}$ loading on their biology, and the need for policy interventions, should be assessed separately. Conflating data from the two areas could lead to spurious conclusions about shifts in the biological or biogeochemical patterns in the bay.

The fact that $52 \%$ of all $\mathrm{N}$ loading to Narragansett Bay passes through just 31 sewage plants, (of which half passes through just five), provides an opportunity to alter the $\mathrm{N}$ dynamics of the bay through engineered denitirification. Tertiary treatment projects currently agreed to will result in modest reductions in overall $\mathrm{N}$ loading to the bay (S1 in Figure 3), but are an important first step in reversing the trend of increasing $\mathrm{N}$ loading, particularly to the heavily impacted waters of the upper bay. Implementing similar $\mathrm{N}$ standards at all sewage treatment facilities would further reduce total loads (S2 in Figure 3), but the overall effect is not dramatic. The strict $\mathrm{N}$ reduction standards modeled in S3 would be costly, but the effect on $\mathrm{N}$ loads would be dramatic: a 50\% reduction in landbased loads relative to business-as-usual. Sewage facilities discharging directly to the Lower Bay might reasonably be excluded from these standards, as Lower Bay is well flushed tidally, and not prone to eutrophication. Scenario 3 shows that reductions in fertilizer use and atmospheric deposition are necessary to bring the Bay back to an early $20^{\text {th }}$ Century baseline; the cost-effectiveness and ancillary benefits of such measures should be examined.

Duarte et al. (2009) caution that reductions in nutrient loads to an earlier level do not necessary imply that ecosystems will return to their former states. There can be a significant time lag before ecosystems respond to reductions, and the final state of the ecosystem may be different from the envisioned baseline state due to changes in other factors. Indeed, increasing nutrient loads (Figure 3) have not been the only significant drivers of change on Narragansett Bay, but occurred along with harvests of economically valuable species, metals pollution, net loss of wetlands, the filling and hardening of the shoreline, the dredging of channels, thermal inputs, and military activities. Sea-level rise, climate change, and invasive species will continue to change the ecology of Narragansett Bay in unexpected ways. The management challenge currently facing Narragansett Bay is substantial, and hinges on the creation of positive rather than negative synergies among these multiple drivers as we manage the Bay as a set of closely coupled systems, each requiring different management interventions.

\section{Acknowldegements}

We thank Scott Nixon for helpful conversations on the history of Narragansett Bay, and two anonymous reviewers for comments and questions that lead to major improvements in this manuscript. 


\section{References}

Alexander, R.B., and R.A. Smith. 1990. County-Level Estimates of $\mathrm{N}$ and $\mathrm{P}$ Fertilizer use in the United States, 1945 to 1985. USGS Open File Report 90130.

Alexander, R.B., R.A. Smith, G.E. Schwarz, S.D. Preston, J.W. Brakebill, R. Srinivasan, and P.A. Pacheco. 2001. Atmospheric N flux from the watersheds of major estuaries in the United States: An application of the SPARROW watershed model. In Nitrogen Loading in Coastal Water Bodies: An Atmospheric Perspective, eds R.A. Valigura, R.B. Alexander, M.S. Castro, T.P. Meyers, H.W. Paerl, P.E. Stacey, and R.E. Turner, 119-170. Washington: AGU.

Allingham, K.D., R. Cartwright, D. Donaghy, J.S. Conway, K.W.T. Goulding, and S.C. Jarvis. 2002. Nitrate leaching losses and their control in a mixed farm system in the Cotswold Hills, England. Soil Use and Management 18:421-427.

Bleken M.A., and L.R. Bakken. 1997. The nitrogen cost of food production: Norwegian society. Ambio 26:134-142.

Bowen, J.L., and I. Valiela. 2001a. The ecological effects of urbanization of coastal watersheds: historical increases in $\mathrm{N}$ loads and eutrophication of Waquoit Bay estuaries. Canadian Journal of Fisheries and Aquatic Science 58:1489-1500.

Bowen, J.L., and I. Valiela. 2001b. Historical changes in atmospheric nitrogen deposition to Cape Cod, Massachusetts, USA. Atmospheric Environment 35:1039-1051.

Boyer, E.W., C.L. Goodale, N.A. Jaworski, and R.W. Howarth. 2002. Anthropogenic nitrogen sources and relationships to riverine nitrogen export in the northeastern USA. Biogeochemistry 57/58:137169.

Briefel, R.R., and C.L. Johnson. 2004. Secular trends in dietary intake in the United States. Annual Review of Nutrition 24:401-431.

Brush, G.S. 2009. Historical land use, nitrogen, and coastal eutrophication: A paleoecological perspective. Estuaries and Coasts 32:18-28.

Campbell, J.L., J.W. Hornbeck, M.J. Mitchell, M.B. Adams, M.S. Castro, C.T. Driscoll, J.S. Kahl, J.N. Kochenderfer, G.E. Likens, J.A. Lynch, P.S. Murdoch, S.J. Nelson and J.B. Shanley. 2004. Input-output budgets of inorganic nitrogen for 24 forest watersheds in the Northeastern United States: A review. Water, Air, and Soil Pollution 151:373-396.

Castro, M.S., C.T. Driscoll, T.E. Jordan, W.G. Reay, W.R. Boynton, S.P. Seitzinger, R.V. Styles, and J.E. Cable. 2001. Contribution of atmospheric nitrogen to the total nitrogen loads to thirty-four estuaries on the Atlantic and Gulf Coasts of the United States. In Nitrogen Loading in Coastal Water Bodies: An Atmospheric Perspective, eds R.A. Valigura, R.B. Alexander, M.S. Castro, T.P. Meyers, H.W. Paerl, P.E. Stacey, and R.E. Turner, 77-106. Washington: AGU.

Castro, M.S., and C.T. Driscoll. 2002. Atmospheric nitrogen deposition to estuaries in the midAtlantic and northeastern United States. Environmental Science and Technology 36:32423249.

Cole, J.J., B.L. Peierls, N.F. Caraco, and M.L. Pace. 1993. Nitrogen loading of rivers as a humandriven process. In Humans as components of ecosystems, eds M.L. McDonnell, and S.T.A. Pickett, 141-157. New York: Springer-Verlag.

Cornell University Agricultural Experiment Station. 1891. The production and care of farm manures. Bulletin 27. Ithaca, NY: Cornell University.

Deacutis, C.F. 2008. Evidence of ecological impacts from excess nutrients in Upper Narragansett Bay. In Science for Ecosystem-based Management: Narragansett Bay in the 21st Century, eds B. Costa-Pierce and A. Desbonnet, 349-381. New York: Springer.

Dise, N., and R.F. Wright. 1995. Nitrogen leaching from European forests in relation to nitrogen deposition. Forest Ecology and Management, 71:153-161.

Doherty, A. 1995. Historical patterns of eelgrass distribution in Narragansett Bay. Providence: Brown University Department of Geological Sciences. Honors Thesis.

Driscoll, C.T., D. Whitall, J. Aber, E. Boyer, M. Castro, C. Cronan, C.L. Goodale, P. Groffman, C. Hopkinson, K. Lambert, G. Lawrence, and S. Ollinger. 2003. Nitrogen pollution in the northeastern United States: sources, effects and management options. Bioscience 53:357-374.

Duarte, C.M., D.J. Conley, J. Carstensen, and M. Sánchez-Camacho. 2009. Return to Neverland: 
Shifting baselines affect eutrophication restoration targets. Estuaries and Coasts 32:29-36.

Fisher, D.C., and M. Oppenheimer. 1991. Atmospheric nitrogen deposition and the Chesapeake Bay Estuary. Ambio 20:102-108.

Fulweiler, R.W., S.W. Nixon, B.A. Buckley, and S.L. Granger. 2007. Reversal of the net dinitrogen gas flux in coastal marine sediments. Nature 448:180182.

Gage, S.D. 1922. Sewerage and Sewage Disposal in Rhode Island. Report of the Board of Purification of Waters.

Gage, S.D., and P.C. McGouldrick. 1925. Report of Investigations of the Pollution of Certain Rhode Island Public Waters during 1923 and 1924. Report of the Board of Purification of Waters for 1923 and 1924.

Galloway, J.N., F. J. Dentener, D.G. Capone, E.W. Boyer, R.W. Howarth, S.P. Seitzinger, G.P. Asner, C.C. Cleveland, P.A. Green, E.A. Holland, D.M. Karl, A.F. Michaels, J.H. Porter, A.R. Townsend, C.J. and Vörösmarty. 2004. Nitrogen cycles: Past, present, and future. Biogeochemistry 70:153-226.

Goodale, C.L., K. Jajtha, K.J. Nadelhoffer, E.W. Boyer, and N.A. Jaworski. 2002. Forest N sinks in large eastern U.S. watersheds: estimates from forest inventory and an ecosystem model. Biogoechemistry 57/58: 239-266.

Hamburg, S.P., D. Pryor, and M.A. Vadeboncoeur. 2008. Nitrogen Inputs to Narragansett Bay: An Historical Perspective. In Science for Ecosystembased Management: Narragansett Bay in the 21st Century, eds B. Costa-Pierce and A. Desbonnet, 177-210. New York: Springer.

Hamlin, C. 1990. A Science of Impurity: Water Analysis in Nineteenth Century Britain. Berkeley: UC Press.

Harper, R.M. 1918. Changes in the forest area of New England in three centuries. Journal of Forestry 16:442-452.

Harris, W.J. 1913. General Statistics of Cities: 1909. US Bureau of the Census.

Haskell, S.B. 1925. Fertilizer Use in the United States. Annals of the American Academy of Political and Social Science 117:265-270.

Howarth, R.W. 2008. Estimating Atmospheric Nitrogen Deposition in the Northeastern United
States: Relevance to Narragansett Bay. In Science for Ecosystem-based Management: Narragansett Bay in the 21st Century, eds B. Costa-Pierce and A. Desbonnet, 44-76. New York: Springer.

Howarth, R.W., G. Billen, D. Swaney, A. Townsend, N. Jaworski, K. Lajtha, J.A. Downing, R. Elmgren, N. Caraco, T. Jordan, F. Berendse, J. Freney, V. Kudeyarov, P. Murdoch, and Z. Zhao-Liang. 1996. Regional nitrogen budgets and riverine N\&P fluxes for the drainage to the North Atlantic Ocean: Natural and human influences. Biogeochemistry 35:75-139.

Howarth, R.W., and R. Marino. 2006. Nitrogen as the limiting nutrient for eutrophication in coastal marine ecosystems: Evolving views over three decades. Limnology and Oceanography 51:364376.

Howarth, R.W., A. Sharpley, and D. Walker. 2002. Sources of nutrient pollution to coastal waters in the United States: Implications for achieving coastal water quality goals. Estuaries 25:656-676.

Johnes, P. 1996. Evaluation and management of the impact of land use change on the nitrogen and phosphorus load delivered to surface waters: the export coefficient modeling approach. Journal of Hydrology 183:323-349.

Lander, C.H., and D. Moffitt. 1996. Nutrient use in cropland agriculture (commercial fertilizer and manure): Nitrogen and phosphorus. USDA NRCS RCA III, Working Paper 14.

Law, N.L., L.E. Band, and J.M. Grove. 2004. Nitrogen input from residential lawn care practices in suburban watersheds in Baltimore County, MD. Journal of Environmental Planning and Management. 47:737-755.

Lipman, J.G. 1929. The economic significance of commercial fertilizers. Annals of the American Academy of Political and Social Science 142:257265

Magill, A.H., J.D. Aber, G.M. Bernston, W.H. McDowell, K.J. Nadelhoffer, J.M. Melillo, and P.A. Steudler. 2000. Long-term nitrogen additions and nitrogen saturation in two temperate forests. Ecosystems 3:238-253.

(MSDH) Massachusetts State Department of Health. 1915. Annual Report. 
Mehring, A.L. 1945. Fertilizer nitrogen consumption. Industrial and Engineering Chemistry 37:289-295.

Mehring, A.L., and A.J. Peterson. 1934. Changes in composition of American fertilizers, 1880-1932. USDA Circular 315.

Meybeck, M., D.V. Chapman, and R. Helmer. 1989. Global freshwater quality: a first assessment. Cambridge, MA: Basil Blackwell.

Meyers, T., J. Sickles, R. Dennis, K. Russell, J. Galloway, and T. Church. 2001. Atmospheric nitrogen deposition to coastal estuaries and their watersheds. In Nitrogen Loading in Coastal Water Bodies: An Atmospheric Perspective, eds R.A. Valigura, R.B. Alexander, M.S. Castro, T.P. Meyers, H.W. Paerl, P.E. Stacey, and R.E. Turner, 53-76. Washington: AGU.

Nixon, S.W. B.A. Buckley, S.L. Granger, L.A. Harris, A.J. Oczkowski, R.W. Fulweiler, and L.W. Cole. 2008. Nitrogen and Phosphorus Inputs to Narragansett Bay: Past, Present, and Future. In Science for Ecosystem-based Management: Narragansett Bay in the 21st Century, eds B. Costa-Pierce and A. Desbonnet, 101-175. New York: Springer.

Nixon, S.W., S.L. Granger, and B.L. Nowicki. 1995. An assessment of the annual mass balance of carbon, nitrogen, and phosphorus in Narragansett Bay. Biogeochemistry 31:15-61.

Novak, A.B., and Y.Q. Wang. 2004. Effects of suburban sprawl on Rhode Island's forests: a Landsat view from 1972 to 1999 . Northeastern Naturalist 11:67-74.

Paerl, H.W., W.R. Boynton, R.L. Dennis, C.T. Driscoll, H.S. Greening, J.N. Kremer, N.N. Rabalais, and S.P. Seitzinger. 2001. Atmospheric Deposition of Nitrogen in Coastal Waters: Biogeochemical and Ecological Implications. In Nitrogen Loading in Coastal Water Bodies: An Atmospheric Perspective, eds R.A. Valigura, R.B. Alexander, M.S. Castro, T.P. Meyers, H.W. Paerl, P.E. Stacey, and R.E. Turner, 11-52. Washington: AGU.

Patenaude, B. 2000. Survey of Wastewater Treatment Facilities in Rhode Island for 1998 and 1999. RI DEM.

Pilson, M.E.Q. 1985. On the residence time of water in Narragansett Bay. Estuaries 8:2-14.
Pryor, D., E. Saarman, D. Murray, and W. Prell. 2007. Nitrogen loading from wastewater treatment plants to Narragansett Bay. Narragansett Bay Estuary Program Report NBEP-2007-126.

Rhode Island Department of Health. 1936. Annual Report. Providence, RI: H. Beck and Co.

Rhode Island Statewide Planning. 2006. Land Use 2025: Rhode Island State Land Use Policies and Plan. Report Number 109; State Guide Plan Element 121.

Roberts, I.P. 1907. The Fertility of the Land. 10th Edition. New York: The Macmillan Co.

Roman, C.T., N. Jaworski, F.T. Short, S. Findlay, and R.S. Warren. 2000. Estuaries of the northeastern United States: Habitat and land use signatures. Estuaries 23:743-764.

Ruddy, B.C., D.L. Lorenz, and D.K. Mueller. 2006. County-Level Estimates of Nutrient Inputs to the Land Surface of the Conterminous United States, 1982-2001. USGS National Water-Quality Assessment Program. Scientific Investigations Report 2006-5012.

Seitzinger, S.P., R.V. Styles, E.W. Boyer, R.B. Alexander, G. Billen, R.W. Howarth, B. Mayer, and N. Van Breemen. 2002. Nitrogen retention in rivers: model development and application to watersheds in the northeastern U.S.A. Biogeochemistry 57/58:199-237.

Smil, V. 1999. Nitrogen in crop production: an account of global flows. Global Biogeochemical Cycles 13: 647-662.

Soll, D.J. 2009. Reforestation in Norfolk County, Massachusetts. In Remaking Boston : an environmental history of the city and its surroundings, eds A.N. Penna and C.E.Wright, 148167. Pittsburgh: University of Pittsburgh Press.

Thomas, G.W., and J.W. Gilliam. 1977. Agroecosystems in the U.S.A. AgroEcosystems 4:182239.

Valiela, I., G. Collins, J. Kermer, K. Lajtha, M. Geist, B. Seely, J. Brawley, and C.H. Sham. 1997. Nitrogen loading from coastal watersheds to receiving estuaries: new method and application. Ecological Applications 7:358-380.

van Breemen, N., E.W. Boyer, C.L. Goodale, N.A. Jaworski, K. Paustian, S.P. Seitzinger, K. Lajtha, B. Mayer, D. Van Dam, R.W. Howarth, K.J. 
Nadelhoffer, M. Eve, and G. Billen. 2002. Where did all the nitrogen go? Fate of nitrogen inputs of large watersheds in the northeastern USA. Biogeochemistry 57/58:267-293.

van der Hoek, K.W., and A.F. Bouwman. 1999. Upscaling of nutrient budgets from agroecological niche to global scale. In Nutrient Disequilibria in Agroecosystems, eds E.M.A. Smaling, O., Oenema, and L.O. Fresco, 57-73. Wallingford, UK: CAB International.

van Horn, H.H. 1998. Factors affecting manure quantity, quality, and use. Proceedings of the Mid-
South Ruminant Nutrition Conference. Texas Animal Nutrition Council, 9-20.

Vollenweider, R. 1968. Les bases scientifiques de l'eutrophisation des lacs et des eaux courants sur l'aspect particulier du phosphore et du l'azote comme facteurs d'eutrophisation Rept. DAS/CSI/68-27, P.

Willett, V.B., B.A. Reynolds, P.A. Stevens, S.J. Ormerod, and D.L. Jones. 2004. Dissolved organic nitrogen regulation in freshwaters. Journal of Environmental Quality 33:201-209. 
Table 1. Parameters used to model fluxes from sewered and unsewered populations, livestock, fertilizers, and atmospheric deposition to Narragansett Bay. Parameters are derived from literature on $\mathrm{N}$ cycling in analogous landscapes where possible.

Human waste $\mathbf{N}$ production and loading estimates

per person waste $\mathrm{N}$ production $\left(\mathrm{kg} \mathrm{N}_{\mathrm{N}}\right.$ person ${ }^{-1} \mathrm{yr}^{-1}$ )

Low Mid High

public sewer discharge (\% of input $N$ )

\section{Summary of above (kg N person ${ }^{-1} \mathrm{yr}^{-1}$ )}

Sewered population loading per person

Sheep

Swine (all)

$\begin{array}{rrr}\text { Low } & \text { Mid } & \text { High } \\ 3 \% & 25 \% & 50 \% \\ 1 \% & 10 \% & 15 \% \\ 3 \% & 20 \% & 50 \% \\ 30 \% & 65 \% & 100 \%\end{array}$


Table 2. Description of the scenarios used to predict N loading in 2015.

\begin{tabular}{|c|c|c|c|c|}
\hline & $\begin{array}{l}2015 \text { SO } \\
\text { Business as usual }\end{array}$ & $\begin{array}{l}2015 \text { S1 } \\
\text { Agreed-to reductions }\end{array}$ & $\begin{array}{l}2015 \text { S2 } \\
\text { Reasonable additional } \\
\text { reductions }\end{array}$ & $\begin{array}{l}2015 \text { S3 } \\
\text { Very aggressive } \\
\text { reductions }\end{array}$ \\
\hline $\begin{array}{l}\text { Sewered human } \\
\text { waste stream }\end{array}$ & $\begin{array}{c}\text { Change is proportional to } \\
\text { growth of sewered } \\
\text { population }\end{array}$ & $\begin{array}{c}\text { Agreed-to improvements in } \\
\text { treatment are } \\
\text { implemented: } 3 \text { facilities } \\
\text { meet a summer standard of } \\
5 \mathrm{mg} \mathrm{N} \mathrm{L}^{-1} \text { and } 6 \text { more meet } \\
\text { a summer standard of } 8, \\
\text { including } 2 \text { that are already } \\
\text { below } 8 \text { without an } \\
\text { enforceable agreement. }\end{array}$ & $\begin{array}{c}\text { All agreed-to } \\
\text { improvements are } \\
\text { implemented, plus all } \\
\text { those currently in } \\
\text { negotiation, plus all RI and } \\
\text { large MA facilities meet a } \\
\text { summer standard of } 8 \\
\mathrm{mg} / \mathrm{l} \text {. }\end{array}$ & $\begin{array}{c}\text { All facilities in the } \\
\text { watershed meet a } \\
\text { standard of } 3 \mathrm{mg} / \mathrm{l} \text { in } \\
\text { summer. }\end{array}$ \\
\hline $\begin{array}{l}\text { Non-sewered } \\
\text { human waste } \\
\text { stream }\end{array}$ & \multicolumn{4}{|c|}{ change is proportional to growth of non-sewered population } \\
\hline Livestock & \multicolumn{4}{|c|}{ same as 2000} \\
\hline $\begin{array}{l}\text { Atmospheric } \\
\text { Deposition }\end{array}$ & \multicolumn{2}{|c|}{ same as 2000} & $25 \%$ reduction from 2000 & $50 \%$ reduction from 2000 \\
\hline Land Cover & \multicolumn{4}{|c|}{ Assume conversion of forest to developed continues at $3 X$ the rate of population growth } \\
\hline Fertilizer & change is proportion & al to population growth & $\begin{array}{l}25 \% \text { reduction in per- } \\
\text { capita use from } 2000\end{array}$ & $\begin{array}{l}50 \% \text { reduction in per- } \\
\text { capita use from } 2000\end{array}$ \\
\hline
\end{tabular}


Table 3. Comparison of total $\mathrm{N}$ flux $\left(\mathrm{Mg} \mathrm{N} \mathrm{yr}^{-1}\right.$ ) observed by Nixon et al. $(1995 ; 2008)$ to our estimates of total $\mathrm{N}$ flux for each major subwatershed of Narragansett Bay.

\begin{tabular}{|c|c|c|c|c|c|}
\hline \multirow[b]{2}{*}{ Watershed } & \multirow[b]{2}{*}{ year } & \multirow[t]{2}{*}{ "observed" } & \multicolumn{3}{|c|}{ Modeled - this study } \\
\hline & & & low & mid & high \\
\hline \multirow[t]{2}{*}{ Pawtuxet } & $1982-3$ & 896 & 360 & 620 & 890 \\
\hline & $2003-4$ & 830 & 430 & 790 & 1,190 \\
\hline \multirow[t]{2}{*}{ Blackstone } & $1982-3$ & 1,834 & 780 & 1,400 & 2,190 \\
\hline & $2003-4$ & 1,381 & 880 & 1,590 & 2,440 \\
\hline \multirow[t]{2}{*}{ Taunton } & $1988-9$ & 1,638 & 790 & 1,680 & 2,800 \\
\hline & $2003-4$ & 1,918 & 860 & 1,770 & 3,000 \\
\hline \multirow[t]{2}{*}{ Whole Watershed } & 1985 & 8,470 & 4,000 & 7,200 & 10,700 \\
\hline & 2003-4 & 8,092 & 4,300 & 8,000 & 11,900 \\
\hline
\end{tabular}


Figure 1. a) Map of study area, with labels for hydrographic features referred to in the text. b) Subwatersheds as defined in the model to correspond to town boundaries. Sewage facilities are shown as circles, by current loading requirements. Locations of water quality data are shown as triangles.
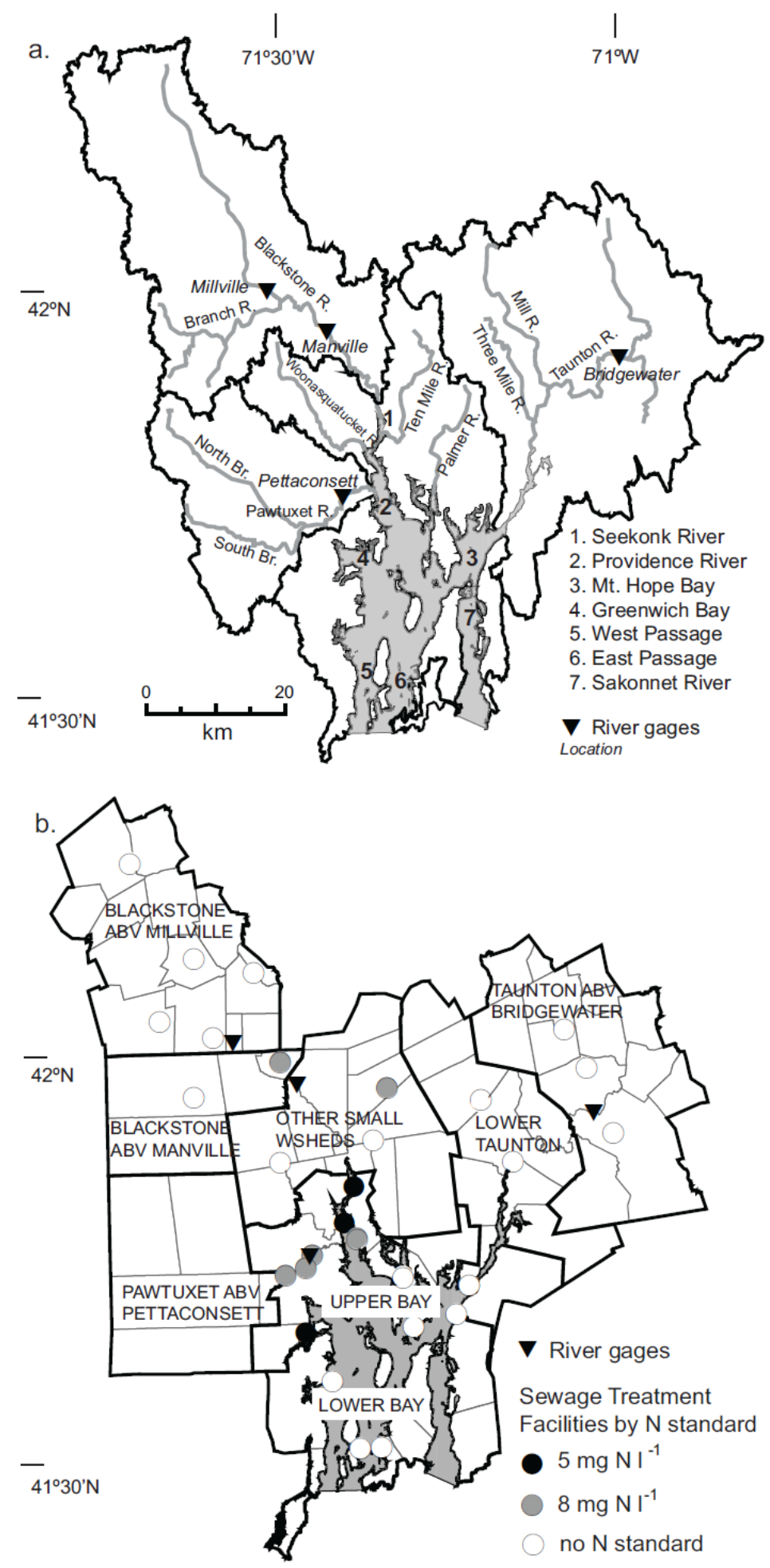
Figure 2. Land-cover in each modeled subwatershed at three points in time. Data from 1850 and 1930 are from town-level agricultural censues. Data from 1992 are from the National Land Cover Dataset. "Active agriculture" includes cleared lands actively cultivated, mowed, or pastured. "Urban/developed" includes areas developed for commercial, residential and infrastructure use with a minimum $30 \%$ impervious cover.
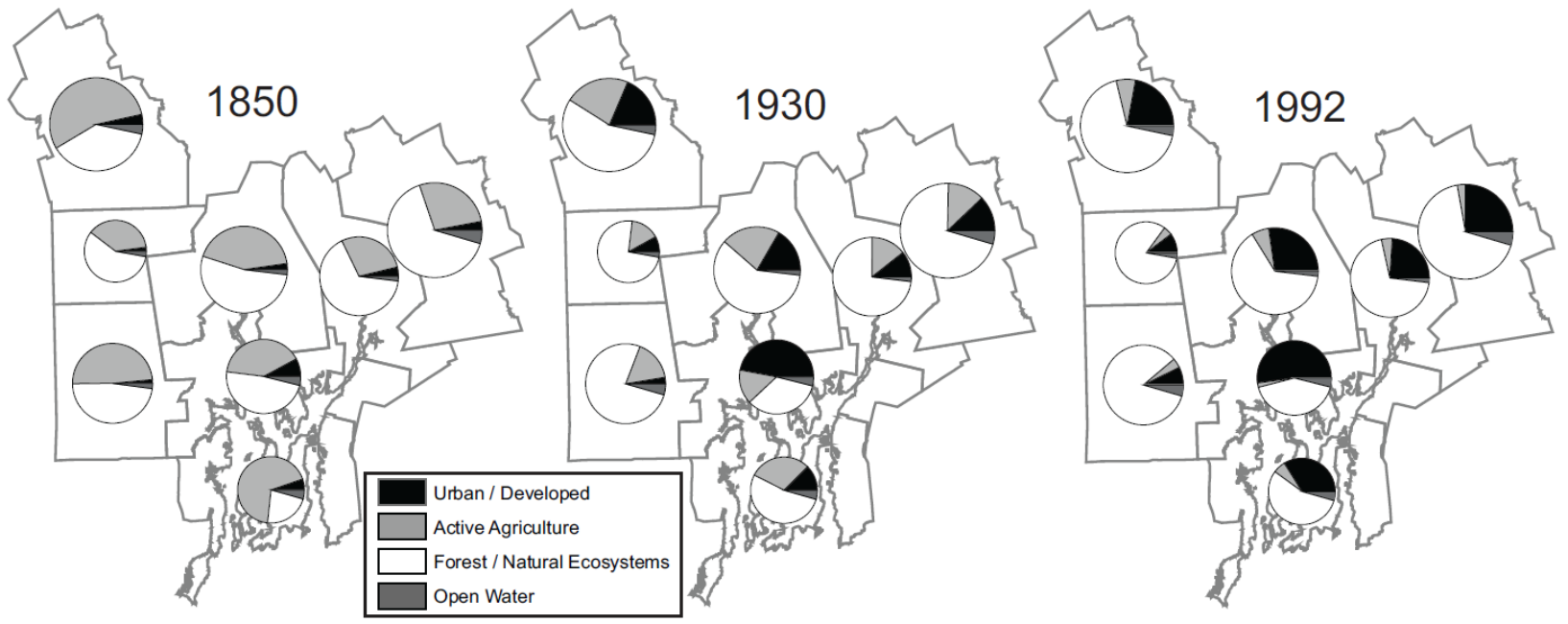
Figure 3. Total annual N loading to Narragansett Bay, 1850-2000, by source (middle estimate). Scenarios S0-S3 are estimates for 2015, using assumptions outlined in Table 2.

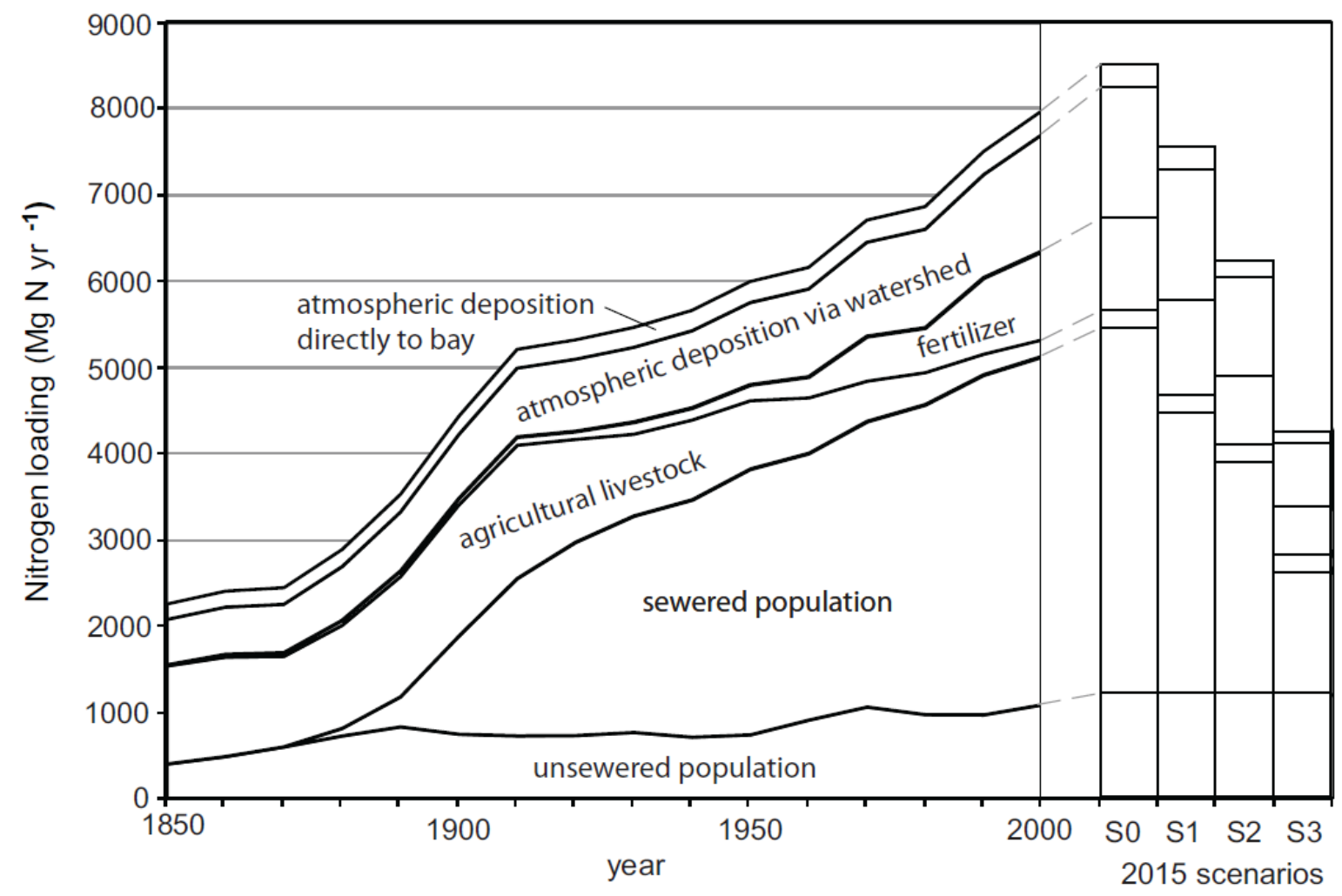


Figure 4. Total annual $\mathrm{N}$ loading (middle estimate) from 1850-2000 in each of six subwatersheds, divided among the five modeled sources of $\mathrm{N}$ : $\mathrm{U}=$ unsewered population, $\mathrm{S}=$ sewered population, $\mathrm{L}=$ livestock, $\mathrm{F}=$ fertilizer, $\mathrm{A}=$ atmospheric deposition.
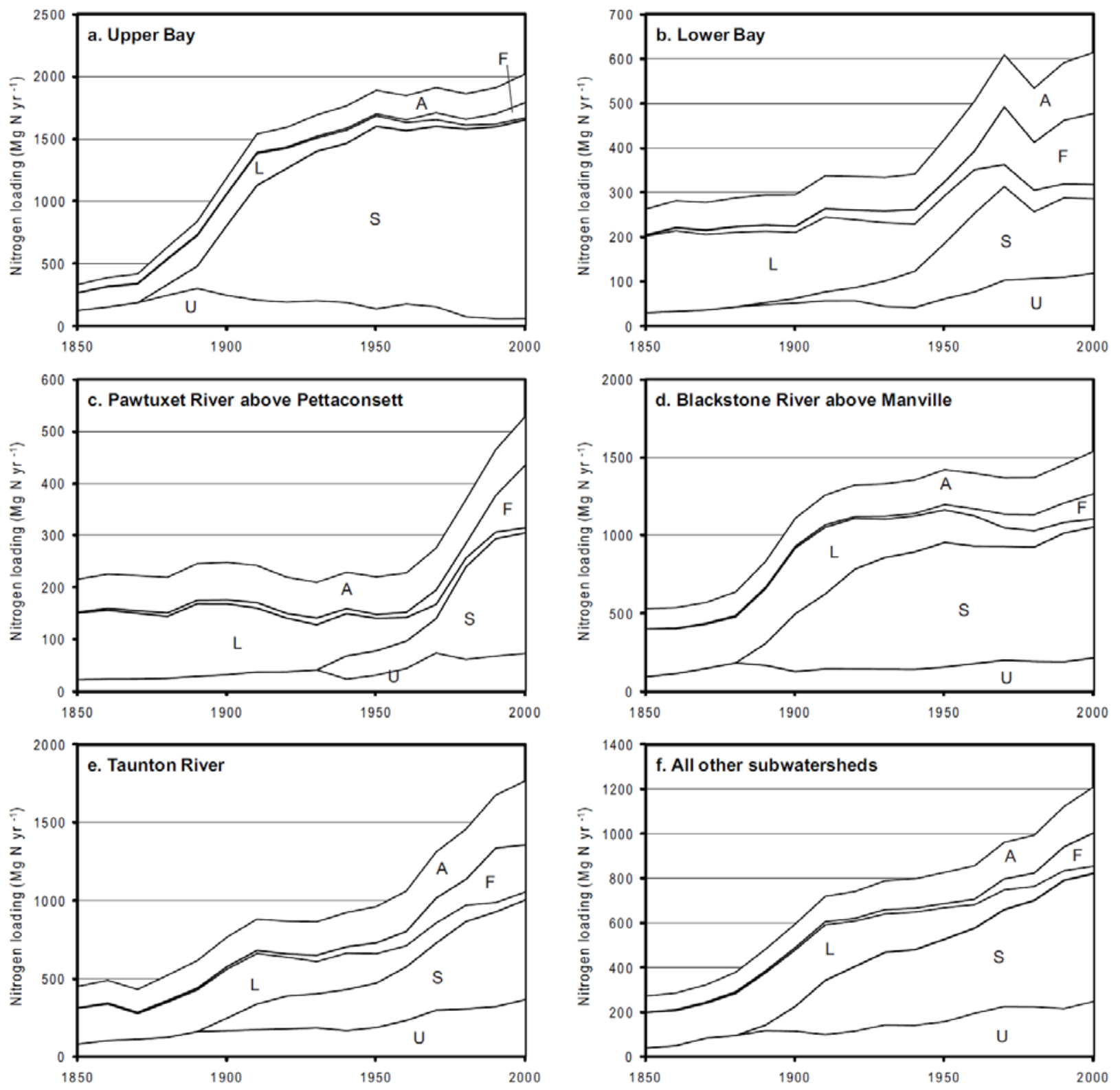
Figure 5. Total annual $\mathrm{N}$ flux (symbols) can be used to validate the modeled estimates presented here (solid and dashed lines). Data are from (a) Taunton/Bridgewater, (b) Pettaconsett, (c) Manville, and (d) Millville.

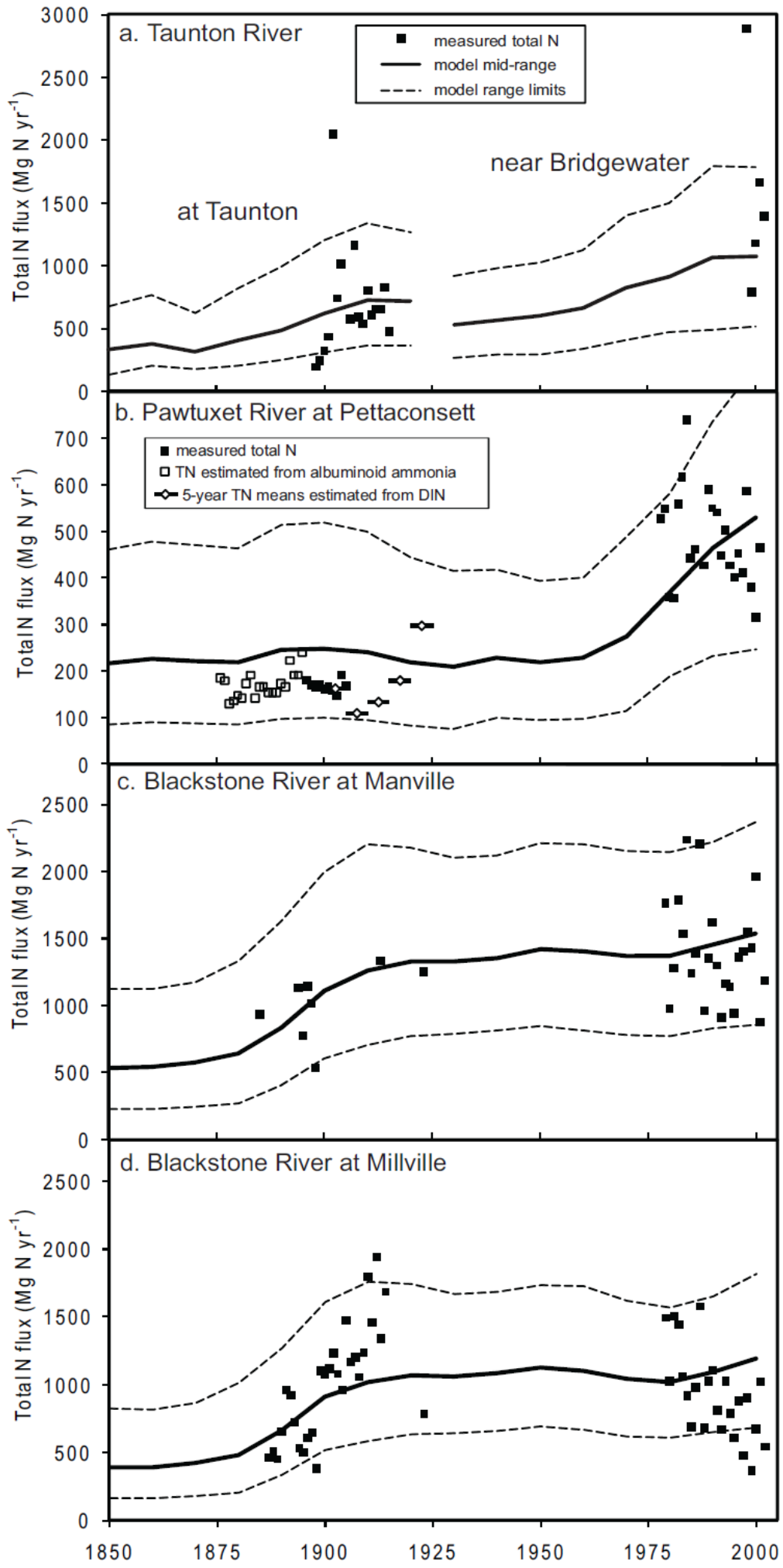

